\title{
Liikkeenjohdon konsultointi - nuori ja kasvava toimiala
}

\author{
Paula Kyrö \\ Liikkeenjohdon konsultoinnin \\ professionaalistumista on Suomessa tutkittu \\ vuosikymmenen puolivälissä. Tutkimuksen \\ mukaan ala on nuori ja vain osittain \\ järjestäytynyt. Konsulttien koulutustaso on \\ kirjava, vaihtuvuus on suuri eikä alalle ole \\ muodostunut markkinasuojaa. Monet ulkoiset \\ muutostekijät luovat kuitenkin tarvetta \\ professionaalistumisprosessin etenemiselle.
}

Liikkeenjohdon konsultointi on nuori toimiala. Se syntyi 1900-luvun vaihteessa ja kasvoi teollistumisen myötä (Kyrö 1992). Profession näkökulmasta liikkeenjohdon konsultointi soveltaa tieteellistä tietoa käytäntöön (Czarniawska-Joerges 1988).

Alan kehityksen voi jakaa markkinoiden volyymin, asiakkaiden ja tuotteiden pohjalta kolmeen vaiheeseen (Kyrö 1992). Alkutaival 1900-luvun vaihteesta 1950-luvulle oli teknisen tiedon ja insinööritaitojen leviämisen aikaa. Liikkeenjohdon konsultoinnin palvelut perustuivat tieteellisen liikkeenjohdon teorianmuodostukseen (esim. Julkunen 1987). Asiakkaina olivat teollisuusyritykset. Ongelmat, joita ratkottiin, liittyivät tuotannon tehokkuuteen. 1950-luvun ja 1960-luvun taitteessa käynnistynyt toinen vaihe jatkui aina 1970luvun lopulle asti. Kehitysvaiheiden murroskohdassa Yhdysvaltojen markkinoiden volyymi ylitti miljardin USD rajan (esim. Greiner-Metzger 1983, 3). Palvelut laajenivat. Markkinoinnin ja edelleen strategisen mallituksen kehityttyä mallitukset nousivat palvelutuotteiksi (esim. Bush 1982, Day \& Wensley 1983, Hunt 1976). Vaihetta hallitsi kuitenkin edelleen tekninen asiantuntemus (esim. Mellet 1988). Toisessa vaiheessa ala järjestäytyi useissa Länsi-Euroopan maissa. Vuonna 1960 perustettiin eurooppalainen kattojärjestö. Sen jäseninä ovat kansalliset järjestöt, jotka vuoden 1994 tietojen mukaan edustavat 1200 liikkeenjohdon konsulttiyritystä. Näiden palveluksessa arvioitiin olevan noin 72000 liikkeenjohdon konsulttia (FEACO 1995).

1980-luku toi räjähdysmäisen kasvun ja monipuolistuvan tuotteiston. 1980-luvun lopulle tultaessa Euroopan markkina-arviot lähentelivät viittä miljardia USD (Feaco 1988). Palvelutarjonta laajeni myös käyttäytymistieteisiin. Vuonna 1987 
syntyi maailmanlaajuinen katto-organisaatio ammatillisen pätevyyden ja sertifioinnin kehittämiseksi. Nykyään liikkeenjohdon konsulttien koulutustausta jakautuu tekniseen, kaupalliseen ja käyttäytymistieteellisiin tutkintoihin.

uomessa liikkeenjohdon konsultoinnin ala
käynnistyi 1930-luvun loppupuolella (Tilastokeskus 1991). Kansainvälisesti Suomella on ollut seurailijan rooli. Järjestäytyminen käynnistyi Suomessa vuonna 1960, kun Suomen liikkeenjohdon konsultit LJK ry. perustettiin. Eurooppalaiseen kattojärjestöön Suomi liittyi vuonna 1961 ja maailmanlaajuiseen organisaatioon vuonna 1990. LJK ry edustaa sekä yrityksiä että yksittäisiä liikkeenjohdon konsultteja. Vuonna 1995 LJK ry:ssä oli 26 yritysjäsentä ja 173 henkilöjäsentä. Oman toimialaluokituksensa liikkeenjohdon konsultointi on saanut vasta vuonna 1986 (Rytkönen, 1989). Toimialaluokituksessa ovat mukana myös markkinatutkimuslaitokset, PR- ja viestintäyritykset sekä tekniset palvelutoimistot. Vuonna 1988 näiden kaikkien yhteenlaskettu liikevaihto oli 1,3 miljardia FIM, vuonna 1996 se oli noin 3,7 miljardia FIM ja yrityksiä oli noin 3500 .

\section{PROFESSIO}

\section{Profession merkitys asiakkaalle}

Kun professio-termiä käytetään toimialojen yhteydessä, halutaan usein osoittaa, että joukko alan yrityksistä toimii muita ammattimaisemmin (esim. Von Glinow 1988, 4-15). Tulkinta voidaan liittää termin semanttisen kehityksen alkujuuriin 1500-luvulle. Professio merkitsi silloin ammattimaisuutta vastakohtana amatöörille. 1500-luvun jälkeen termi sai uusia merkityksiä. Sillä alettiin viitata ensin yleensä ammattiin. Vähitellen kuvauksen painopiste siirtyi profession erityislaatuisuuteen muihin ammatteihin nähden (esimerkiksi Freidson 1986, Larson 1979, Raivola 1989). Keskustelussa painottui profession integroiva ja altruistinen rooli yhteiskunnassa (Collins 1990, Johnson 1986, Parsons 1954). Kritiikkinä tälle ajattelulle syntyi vastakkainen koulukunta, joka kohdisti huomionsa professioihin liittyvään valtaan (Friedson 1986, Konttinen 1991).

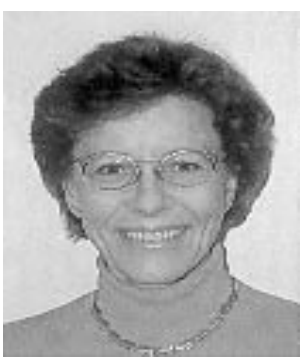

Paula Kyrö

Nykyisen professiokeskustelun huomio on siirtynyt vallasta markkinoiden, verkostoitumisen ja organisaatioiden välisten suhteiden tutkimiseen. Sen keskeisiä kohteita on professioiden monopoliasema markkinoilla (esim. Thompson \& al. 1991). Painopisteen muutos on tuonut mukanaan kritiikin, joka on kyseenalaistanut professioiden tarpeellisuuden yhteiskunnassa. Kritiikkiä leimaa sosiologinen ajattelu, jossa keskitytään profession ja yhteiskunnan väliseen suhteeseen. Keskustelussa on laiminlyöty markkinoiden kannalta olennainen seikka; profession merkitys asiakkaalle. Asiakkaan näkökulma edellyttää liiketalouden teorioiden liittämistä tarkasteluun.

乙eskeinen kysymys professioiden muotoutumisen ja säilymisen kannalta on niiden merkitys asiakkaalle. Professio tarjoaa kriteerit osaamispalvelun hankintaan ja arvioimiseen. Se takaa myös palvelun sisällön ja laadun. Samoin profession avulla muodostuvat toimialan ammatilliset ja eettiset pelinsäännöt. Cyert ja March (1963) nostivat jo 1960-luvulla esiin nämä ongelmat palveluita ostavan organisaation näkökulmasta. Heidän mukaansa, jos ammatteja ei olisi, organisaatioille koituisi kohtuuttomat kustannukset valintaprosessista ja toisaalta kohtuuton riski epäpätevän palvelun käyttämisestä. Tulevaisuudessa nämä ongelmat korostuvat, koska pitkäaikaisten työsuhteiden ennustetaan korvautuvan yhä enemmän projektinomaisella palvelujen käytöllä. Ilman professiota palvelujen hankinta ja käyttö saattaa muodostua asiakkaalle ylivoimaiseksi.

Liikkeenjohdon konsultoinnin asiakkaat ovat käytännössä kohdanneet nämä ongelmat. Palvelun valintakriteereissä ovat korostuneet referenssityöt ja aikaisemmat kokemukset palvelun käytöstä. Kun 
alalle tulolle ei ole ollut esteitä, osaamaton asiakas on kohdannut hyvin kirjavan palvelutarjonnan ja sen tuomat riskit. Kansainväliset tutkimukset raportoivat jopa 94 prosentin lukemia alalta poistumisesta 3-5 vuoden kuluessa (Bryson 1990, Henderson 1990, Teipel 1990, 35). Poistuma koskee mikroyrityksiä, joissa korostuu henkilösidonnainen osaaminen. Mikroyritysten laatua on vaikea kehittää muutoin kuin professionaalistumisprosessin avulla. Yhdistämällä toimiala ja professio pyritään nostamaan esiin asiakassuuntautunutta keskustelua professioista ja niiden merkityksestä ostoprosessissa.

\section{Toimialan ja profession yhdistäminen}

Kun professio yhdistetään toimialaan, kiinnitytään myöhäisempään tulkintaan professiosta ammattina, jota määrittää eriytynyt tiedeperusta ja siihen liittyvä koulutus. Professio kuvaa silloin joukkoa ihmisiä, joilla on samanlainen koulutuksellinen tausta, siihen liittyvä tiedeperusta ja näihin molempiin liittyvä yhteiskunnan hyväksyntä ammatillisine ja eettisine normistoineen. Profession kehittyminen on monimuotoinen prosessi, joka syntyy eri elementtien vuorovaikutuksessa. Vuorovaikutusprosessissa voidaan tunnistaa neljä rakenteellista tekijää (esimerkiksi Konttinen 1991, 29 ):
1. Eriytynyt/erikoistunut tiedeperusta

2. Suhteellisen laaja työautonomia

3. Professionaaliset organisaatiot

4. Professionaaliset strategiat, joissa painottuu sosiaalinen vastuu (tällä viitataan sekä eetti siin normeihin yhtä hyvin kuin kvalifikaatioihin tai ammatillisiin normeihin, (=ethi cal and professional codes of conduct)

Autonomia ja eriytynyt tiedeperusta liittyvät toisiinsa, koska työautonomian aste juontaa juurensa tieteelliseen tiedeperustaan. Autonomisuuden vuoksi professiopalvelujen standardointi yritysten toimesta on vaikeaa. Se tapahtuukin professionaalistumisprosessissa, johon liittyvät professionaaliset organisaatiot ja strategiat. Kuviossa 1 on jäsennetty näitä tekijöitä.

$P_{n}$ rofessiot erotetaan muista ammateista eriytyneen tiedeperustansa avulla (esimerkiksi Larson 1990). Sen luominen on osa profession haltijoiden tuotantoprosessia. Koulutus, joka perustuu eriytyneeseen tieteelliseen tietoperustaan, on toinen professionaalistumisen elementti (esimerkiksi Parsons 1965). Koulutus luo professiopalvelujen tuottajien joukon, jolle yhteiskunta antaa oikeuden tuottaa näitä palveluja. Koulutus myös luo professiopalvelulle identiteetin, joka antaa asiakkaalle palvelun valinta- ja arviointikriteerit.

KUVIO 1. Professionaalistumisen elementit

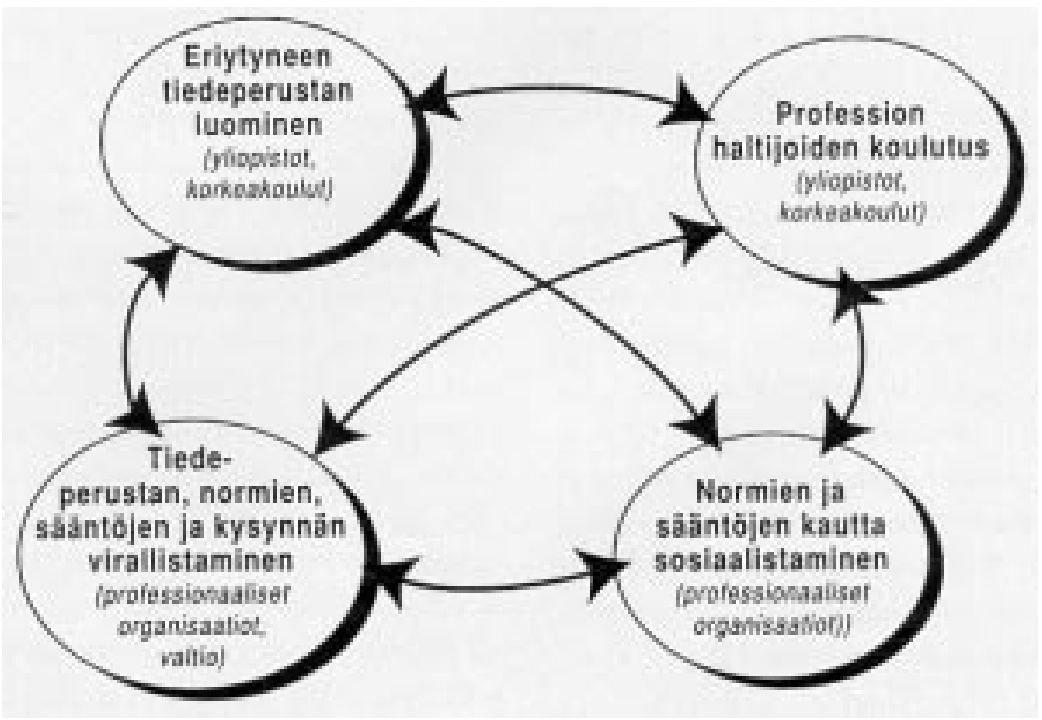


Professionaaliset organisaatiot puolestaan luovat ja kontrolloivat normeja ja käyttäytymissääntöjä. Näin koulutuksesta, joka perustuu eriytyneeseen tiedepohjaan, ja käyttäytymisnormeista ja säännöistä yhdessä muodostuu profession haltijan sosiaalistumis/tamisprosessi. Valtiolla on siinä keskeinen rooli. Se legitimoi eli virallistaa keskeiset professionaalistumisen elementit, vahvistaa sen sisällön, organisoi koulutusta ja myöntää profession haltijoille oikeuksia mm. lainsäädäntöteitse. Kun professio on täysin kehittynyt, etuoikeudet takaavat professiolle monopoliaseman markkinoilla. Freidson (1986) kutsuu tätä markkinasuojaksi, joka estää muiden kuin alalle koulutettujen tulon markkinoille. Markkinasuoja on merkki kypsästä professiosta Sen saavat ainoastaan alat, jotka ovat yhteiskunnalle niin merkityksellisiä, että se haluaa kontrolloida ja/tai varmistaa palvelujen laadun ja saatavuuden. Itse asiassa yhteiskunta luo professiopalvelun. Kansalaiset etsivät ensi sijassa lääkärin tai lakimiehen palveluja ja vasta sitten tietyn profession haltijan tai yrityksen osaamista.

$\mathrm{P}$ rofession liittäminen toimialaan ei ole ongelmatonta. Sekä liiketaloustieteet että sosiologia erottavat markkinat ja valtion toisistaan. Markkinat muodostuvat yksityisen sektorin kysynnästä ja tarjonnasta. Valtio puolestaan on nähty muodossa tai toisessa markkinoiden valvojana ja säätelijänä. Kun kysynnän ja tarjonnan halutaan kohtaavan samalla toimialalla, valtion rooli monipuolistuu ja korostuu. Se muodostaa osan kysynnästä ja toisaalta se on osa professiopalvelun tuotantoprosessia virallistaessaan ja organisoidessaan professioita.

\section{TOIMIALA}

\section{Toimialan muodostamisen kriteerit}

Toimialan käsite on alunperin kehittynyt kuvaamaan teollisuusyrityksiä (esimerkiksi Scherer 1980). Toimialalla on tarkoitettu homogeenista markkinoilla toimivien yritysten joukkoa. Kun toimiala yhdistetään professioon, voidaan muodostaa ketju yhteiskunnan luomasta tuotteesta yrityksen osaamiseen ja edelleen profession haltijan eli yksilön osaamiseen.
$\mathrm{T}$ oimialaa voidaan lähestyä kahdesta eri tarkastelukulmasta: mikroekonomian toimialateorioiden (the industrial economics) tai strategisen suunnittelun mallien avulla. Mikroekonomian toimialateorioissa toimiala muodostetaan joko tarjonnan eli teknologian, tai kysynnän eli markkinoiden lähtökohdista (esimerkiksi Koutsoyiannis 1985). Tarjontalähtöisen kriteerin mukaan toimiala muodostuu yrityksistä, joilla on samanlaiset tuotantomenetelmät, raaka-aineet tai jakelukanavat, esimerkiksi puu, metalli jne. Markkinointikriteerin mukaan taas toimiala muodostuu yrityksistä, jotka täyttävät samanlaisia markkinoiden odotuksia. Samanlaisuutta mitataan tuotteiden korvaavuudella. Laajassa merkityksessä kaikki tuotteet voivat korvata toisiaan. (Kyrö 1995)

Kun toimialakriteerejä tarkastelee yhdessä, ne johtavat eri toimialoihin. Jos ostaja haluaa huonekalun (markkinointikriteeri), se voi olla valmistettu esimerkiksi metallista, puusta tai muovista (teknologiakriteeri). Yrityksen kannalta kriteerit ovat myös hankalia, koska yritys asemoituu eri toimialaan tarjonnan ja kysynnän lähtökohdista. Yritys tarvitseekin integroidun lähestymistavan, jonka avulla sen kysyntää ja tarjontaa koskevat päätökset kohtaavat. Kuvattaessa toimialaa profession avulla päästään sekä kysynnän että tarjonnan kannalta samaan lopputulokseen, kun otetaan avuksi srategisen suunnittelun malleista arvoketjuajattelu.

\section{Toimiala arvoketjuna}

Strategisen suunnittelun mallit ovat pyrkineet kehittämään erilaisia ratkaisuja toimialan rinnalle tai sijaan asemoidakseen ja käsitelläkseen yrityksiä kilpailuympäristössä (esimerkiksi Abell 1980, Minzberg,-Quinn 1991, Porter 1980). Näistä mallituksista löytyy arvoketjuajattelu. Arvoketjun idea syntyi alun perin yrittäjyyden kuvaajan Richard Cantillonin toimesta 1700-luvulla (Kyrö 1997). Se nousi uudelleen esiin markkinoinnin 19201930 luvun teorioissa (Bartels 1962). 1970-luvulla liikkeenjohdon konsulttiyritys McKinsey \& Co loi liiketoimintaketjun käsitteen. Vihdoin vuonna 1985 Michael Porter lanseerasi termin arvoketju kilpailuedun analysointivälineeksi. 
KUVIO 2. Professiopalvelun arvoketju

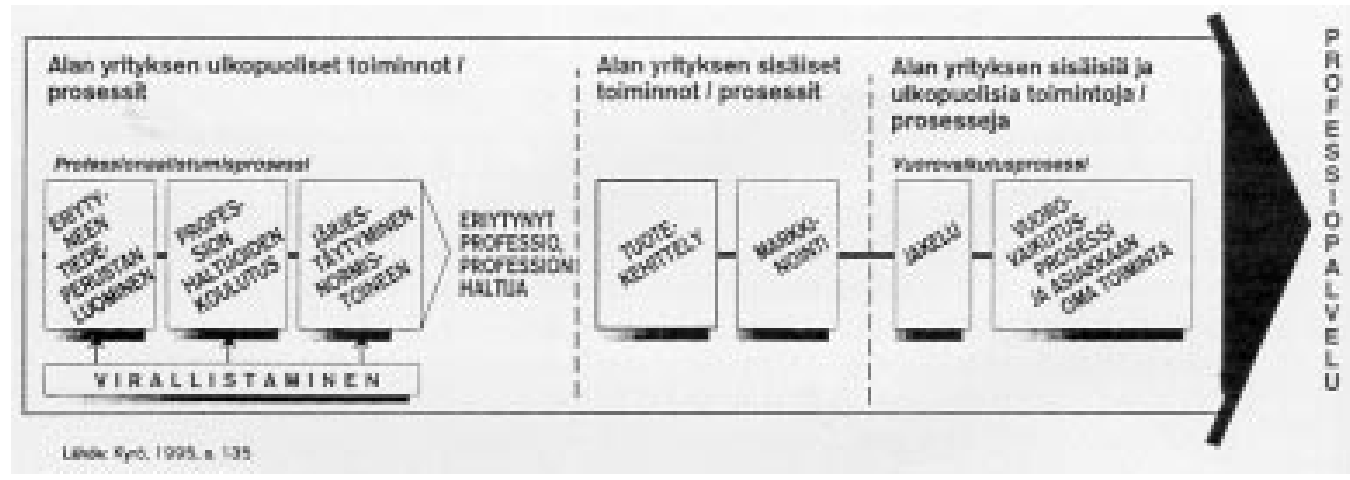

A rvoketju koostuu kaikista toiminnoista, jotka tarvitaan ostajan odotusten täyttämiseksi. Ketju sisältää myös asiakkaan toiminnan palvelun tuottajana (Gilbert \& Strebel 1991, 84). Jokaisen arvoketjun sisältämän toiminnon tulee lisätä tuotteen arvoa asiakkaalle. Kun professio määrittāä toimialaa, on mahdollista muodostaa toimiala yrityksistä, joilla on samanlainen arvoketju.

Arvoketju täyttää toimialan muodostamisessa sekä tuotanto-, että markkinointikriteerin. Se muodostuu markkinoiden odotuksista. Myös teknologia, jolla professiopalvelu tuotetaan, on kullakin professiolla homogeeninen. Tuotanto ei koostu perinteiseen tapaan ainoastaan alan yrityksen toimista, vaan siihen sisältyy myös professionhaltijoiden tuottaminen. (Professiopalvelujen luonteesta ja niiden kytkeytymisestä profession haltijan käyttäytymiseen esimerkiksi Larson 1979). Itse asiassa profession haltijat ja heidän toimintansa muodostaa tuotteen, joka ilmenee ja rakentuu heidän käyttäytymisensä kautta. (Esimerkiksi Freidson, 1986, Larson 1979, Parsons 1954). Profession heterogeenisuuden ja henkilösidonnaisuuden vuoksi yritykset eivät voi standardoida niitä. $\mathrm{Ne}$ ainoastaan rakentavat osaamisesta erilaisia tuotekonsepteja eli diversifioivat ja edelleen markkinoivat niitä.

\section{Asiakas osaksi arvoketjua}

Koska tuotteen hyödyntäminen kuuluu arvoket- juun, liittyvät myös asiakkaat ja heidän toimintansa osaksi tuotantoprosessia. Professiopalveluissa asiakkaan rooli korostuu. Lopullinen tuote ei ole valmis ilman asiakkaan omaa toimintaa. Tämä näkemys on alkanut korostua vakiintuneissa professioissa, kuten hoitoalalla ja oppimisessa. Niissä on havaittavissa ihmiskäsityksen muutos, joka korostaa hoidettavan tai oppijan oman toiminnan merkitystä hoito- tai oppimistuloksen muodostumisessa. Myös palvelujen markkinoinnin teoriat painottavat palvelujen heterogeenisuutta samoin kuin asiakkaan välttämätöntä osallistumista tuotantoprosessiin (esimerkiksi BenndorfHenriksson 1989, Zeithaml \& al. 1989).

Kysyntä ja tarjonta professiopalveluissa ovat toisistaan erottamattomia ja vuorovaikutuksessa keskenään. Vuorovaikutuksellisuus laajentaa edelleen perinteisen tuotantoprosessin käsitettä. Yhdistämällä em. tekijät (kuvio 2) professiopalvelun arvoketju eli tuotantoprosessi muodostuu kolmesta erityyppisestä toiminnasta ja prosessista:

1. Profession haltijoiden tuottamisesta (yrityksen ulkopuolinen prosessi)

2. Toimialan yritysten sisäisistä toiminnoista, jotka tarvitaan tuotteiden erilaistamiseen ja markkinointiin (perinteinen ajattelu tuotantoprosessista)

3. Vuorovaikutusprosessista asiakkaan ja profes sion haltijan välillä sekä asiakkaan omasta toi minnasta. Toiminnat ovat luonteeltaan sekä yrityksen sisäisiä että ulkopuolisia. 
A siakkaan odotukset puolestaan kohdentuvat ensisijaisesti professiopalveluun ja vasta toissijaisesti tiettyyn professionhaltijaan tai professiopalveluita markkinoivaan yritykseen. Näin yksilötason ja yhteiskunnan tason toiminnat kohtaavat ja arvoketjusta muodostuu ympyrä. Tuloksena on laajentunut tuotantoprosessin käsite ja integroitunut lähestymistapa toimialaan. Arvoympyrä täyttää toimialan muodostumisessa sekä markkinointi- että teknologiakriteerin. Teknologia professiopalvelujen tuottamisessa on professionaalistuminen/aminen ja markkinoiden odotukset kohdentuvat professioon, jonka määrittämänä arvoympyrä on rakentunut.

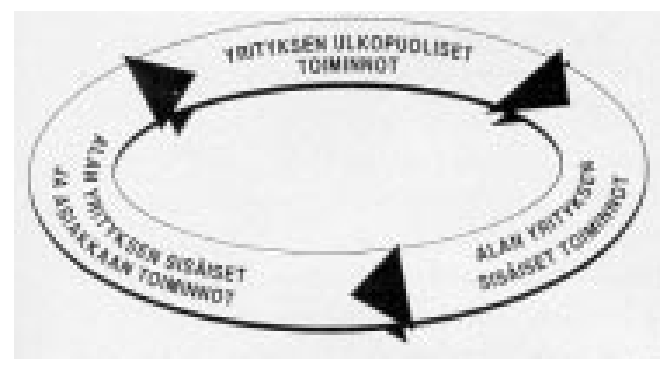

KUVIO 3. Arvoympyrä professiotoimialalla

Kun professio on muotoutunut, toimialan toimintalogiikkaa määräytyy profession luomien pelinsääntöjen pohjalta. Se ei ole, kuten modernin ajan liiketaloustiede on olettanut, kysynnän ja tarjonnan rationaalisesti muodostama kilpailutilanne, vaan sitä ohjaavat normistot ja arvot, jotka yhteiskunta on professiolle määrittänyt. Usein yhteiskunta on professiossa myös keskeinen ostaja. On tärkeä oivaltaa profession merkitys toimialan muotoutumisessa ja toiminnassa, koska yhteiskunta on parhaillaan luomassa uusia pelinsääntöjä aloille, joilla se on toiminut monopoliasemassa palvelun tuottajana ja ostajana.

Professiotoimialan tutkimuksessa huomio voidaan kohdistaa eri professionaalistumisen elementteihin ja kuvata niiden avulla sekä professionaalistumisen astetta että alan luonnetta. Liikkeenjohdon konsulteilla on tiedeperusteinen koulutus, jota he käyttävät työssään. Alalla ei kuitenkaan ole omaa erillistä tiedeperustaansa, vaan toimijoilla on useita erilaisia koulutustaustoja. Siinä suhteessa se ei ole muotoutunut professioksi. Ala on kuitenkin järjestäytynyt ja sillä on omat ammatilliset ja eettiset normistonsa. (Kyrö 1995) Alan professionaalistumisen tilannetta voidaan tutkia markkinarakenteen ja markkinasuojan eli alalle tulon ja sieltä poistumisen avulla.

\section{Markkinarakenne kilpailutilanteen kuvaajana}

Markkinarakenne kuvaa yritysjoukkoa, joka toimii samassa kilpailuympäristössä. Sen avulla on mahdollista analysoida palvelujen tarjoajien asemaa suhteessa toisiinsa. (esimerkiksi Porter 1980) Mitä enemmän markkinat ovat keskittyneet, sitä harvempia yrityksiä markkinoilla kilpailee (esimerkiksi Lahti 1985). Professori Arto Lahden mukaan yritysrakenteilla on pyrkimys polarisoitua. Ydinmarkkinat muodostuvat suuryrityksistä. Niiden kilpailutilanne on oligopolinen ja asema suhteellisen vakaa. Loput markkinoista muodostuvat pienten ja keskisuurten yritysten tarjonnasta (Lahti 1991, 151).

Professiotoimialoilla kaksikerroksinen kuvaus on ongelmallinen. Sen avulla ei saada tietoa profession muotoutumisen keskeisestä tekijästä, markkinasuojan muodostumisesta. Kun lisäksi professiopalvelu on yksilön osaamiseen sitoutuva tuote, joka ei välttämättä edellytä suuria investointeja, profession haltija voi myydä omaa osaamistaan itsenäisenä toimijana. Pienten ja keskisuurten yritysten tarkastelu yhtenä markkinakerrostumana ei tavoita yksittäisten toimijoiden todellisuutta. Kolmanneksi eri kerrostumien tarkastelu toisistaan riippumattomina kilpailuympäristöinä ei ota huomioon verkostoitumista eli kilpailuympäristöä, jossa on useita erilaisia toimijoita. Valtion keskeinen rooli professiopalvelun tuottamisessa ei mahdu perinteisen markkinarakennetarkasteluun, missä julkinen sektori ja markkinat on erotettu toisis- 


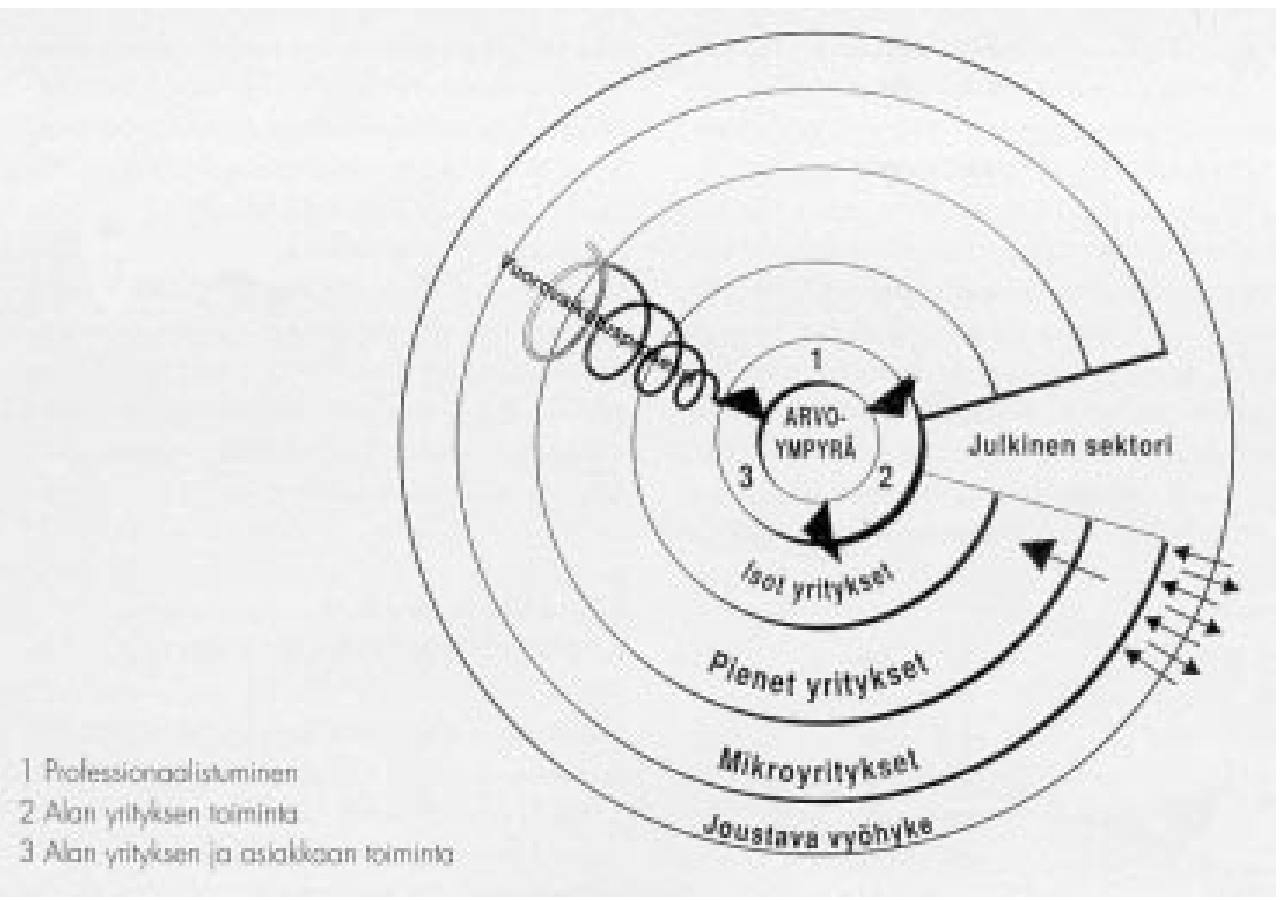

KUVIO 4. Kolmikerroksinen markkinarakenne (Kyrö, 1996)

taan. (Valtion roolista ja sen kysynnän luonteesta esimerkiksi Weber 1969, Larson 1979, Levacic 1991). Kun nämä tekijät otetaan huomioon, markkinoiden polarisoitunut kuva monimuotoistuu.

$\mathrm{M}$ arkkinat muodostuvat kolmesta kerrostumasta: suurista ydinyrityksistä, pienistä ja keskisuurista yrityksistä sekä mikroyrityksistä. Eri markkinakerrostumat eivät ole erillisiä, vaan vuorovaikutuksessa toistensa kanssa. Valtio on kaikissa kerrostumissa osa markkinarakennetta. Professiossa markkinoiden ytimen muodostaa profession arvoketju, joka säätelee ja ohjaa markkinoiden toimintalogiikkaa. Profession kypsyyttä taas kuvaa alalle tulo ja sieltä poistuminen. Kuviossa 4 sitä kutsutaan joustavaksi vyöhykkeeksi. Kypsässä professiossa markkinasuoja estää muiden kuin alalle koulutettujen harjoittamasta ammattia eli markkinoita hallitsee profession sisäinen monopoli. Keskeneräisessä professionaalistumisprosessissa taas markkinoille tulo on vapaa ja sallii kaikkien halukkaiden kokeilla sillä. Tulevaisuudessa eri markkinakerrostumien vuorovaikutus korostuu, kun verkostuminen kehittyy ja palvelujen institutionaaliset ostajat lisääntyvät EU:n myötä.
Liikkeenjohdon konsultoinnin maailmanlaajuisessa kartoituksessa havaittiin, että markkinat ovat rakentuneet kolmikerroksisiksi ja alalta poistuminen on vilkasta (Kyrö 1992).

MARKKINARAKENNEMALUISSA yhdistyy professiotoimialan kuvauksen viitekehys. Mallin rakentumista ohjaavat profession lähtökohdat ja ominaispiirteet sekä profession että asiakkaan näkökulmista. Siinä yhdistyvät professioissa keskeiset eri tasojen, makro-, mikro- ja yksilötason toimijat. Malli ottaa myös huomioon toimintaympäristön ja problematiikan, jossa professiopalvelut tuotetaan. Viitekehyksen muotouttamisessa on jouduttu rikkomaan joitakin perinteisen liiketaloudellisen ajattelun ja sosiologian raja-aitoja, kuten tuotantoprosessin käsite ja valtion rooli. Tuotantoprosessia laajentamalla ja valtion roolia monipuolistamalla on kuitenkin saavutettu kokonaisvaltainen näkemys professiotoimialasta. Myös liikkeenjohdon konsultoinnista saatujen kansainvälisten empiiristen tulosten pohjalta markkinarakennemalli tuntuu perustellulta. Seuraavaksi sovellan viitekehystä Suomen liikkeenjohdon konsultoinnin markkinoiden kuvaukseen. 


\section{SUOMEN LIIKKEENJOHDON KONSULTOINNIN MARKKINAT}

\section{Tutkimuksen kuvauskohteet ja toteutus}

Suomen liikkeenjohdon konsultoinnin toimialan kuvauksessa jaettiin markkinat edellä kuvatulla tavalla kolmeen markkinakerrostumaan: 1. yli 19 henkeä työllistäviin isoihin ydinyrityksiin, 2. pieniin 5-19 hengen yrityksiin ja 0-4 henkeä työllistäviin mikroyrityksiin. 0-hengen luokka tarkoittaa yrityksiä, jotka työllistivät osittain tai kokonaan yrittäjän itsensä.

$\mathrm{P}_{\mathrm{k}}$ rofessiopalvelun arvoketjua analysoitiin markkinakerrostumittain. Professionaalistumisprosessia kuvattiin koulutuksen luonteen, tason ja koulutusalan sekä järjestäytymisen avulla. Yritysten palvelutarjontaa kuvattiin liikevaihdon jakautumisella maantieteellisesti, palveluiden jakautumisella toiminta-alueittain (field of activity), asiakkaan toimialan ja toimintasektorin mukaan. Jotta tiedot olisivat kansainvälisesti vertailukelpoisia, toiminta-alueessa käytettiin Euroopan kattojärjestön FEACO:n jaottelua ja toimialoissa NACE:n luokittelua. Aineistonkeruu suoritettiin kyselynä. Tiedot kerättiin tilikaudelta 1994. Markkinoille tuloa ja sieltä poistumista eli joustavaa vyöhykettä kuvattiin Tilastokeskuksen virallisen yritystilastojen 1991-1993 pohjalta. Kysely lähetettiin kaikille kahdelle suurinta luokkaa edustavalle yritykselle. Mikroyrityksistä otettiin Tilastokeskuksen aineistosta systemaattinen otanta. Lisäksi kysely lähetettiin kaikille LJK ry:n ja PKT-säätiön konsultti- rekisterin yrityksille.Vastauksia kertyi yhteensä 536 yritykseltä. Näistä 321 vastasi kyselyyn ja 215 ilmoitti, ettei se harjoita liikkeenjohdon konsultointia tai että sen harjoittaminen on vähäistä. Vastaukset heijastelevat alan tiedonkeruun ongelmia. Liikkeenjohdon konsultoinnissa (TOL 7414) mukana ovat myös markkinatutkimuslaitokset, PRja viestintäyritykset sekä tekniset palvelutoimistot. Kun alkuperäisestä joukosta karsittiin muun alan yritykset, muodostui perusjoukko ja vastaajien jakaumat taulukon 1 mukaisiksi.

$\mathrm{K}$ un Tilastokeskuksen toimialaluokan liikevaihdosta oli puhdistettu muuta kuin liikkeenjohdon konsultointia harjoittavat yritykset ja liikkeen-johdonkonsultointia harjoittavien yritysten muu toiminta, alan liikevaihdoksi muodostui noin 1.7 miljardia mk ja yritysten lukumääräksi noin 2 600. Tästä perusluvusta on laskettu vastanneiden yritysten liikevaihdon osuudet. Kyselyyn vastasi 20 prosenttia alan liikevaihdosta. Vastausaktiivisuus vaihteli eri markkinakerrostumien kesken. Vastanneiden mikroyritysten osuus oli 12 prosenttia, pienten yritysten 20 prosenttia ja suurten 54 prosenttia kunkin kerrostuman liikevaihdosta. Kokonaisuutena ottaen voidaan sanoa, että edustavuus on hyvä - suurten yritysten kohdalla jopa erinomainen. Aineistosta pystyttiin tuottamaan ainoastaan suoria ja suhteellisia jakaumia sekä ristiintaulukointeja. Tulokset edustavat vastanneiden yritysten antamaa kuvaa alasta. (Tähän liittyviä ongelmia ja tutkimuksen validisuutta ja reliabilisuutta on perusteellisemmin käsitelty julkaisuissa Kyrö 1996a ja b). Seuraavassa raportoidaan lyhyesti tutkimuksen keskeiset tulokset markkinakerrostumittain.

TAULUKKO 1. Kyselytutkimuksen perusjoukko ja kohdejoukko

\begin{tabular}{|llll|}
\hline YRITYKSENKOKO & PERUSJOUKKO & KOHDEJOUKKO & $\%$ PERUSJOUKOSTA \\
Yli 20 henkilöä & 18 & 18 & 100 \\
5-19 henkilöä & 160 & 160 & 100 \\
0-4 henkilöä & 4205 & 1279 (otos) & 29 \\
YHTEENSÄ & 4383 & 1457 & 33 \\
& & & \\
\hline
\end{tabular}


Markkinakerrostumien merkittävyys ja luonne markkinarakenteessa

Liikkeenjohdon konsultoinnin markkinat Suomessa ovat tulosten mukaan rakentuneet kolmikerroksisiksi. Kullakin markkinakerrostumalla on merkittävä osuus ja asema markkinarakenteessa. Alan profiilista on koottu yhteenveto taulukkoon 2 .

\section{Markkinakerrostumat}

Mikroyritykset keskittyivät sekä liikevaihdon että henkilöstön perusteella muita kerrostumia enemmän liikkeenjohdon konsultointiin. Yritysten liikevaihdosta 82 prosenttia muodostui liikkeenjohdon konsultoinnista ja henkilöstöstä 81 prosenttia oli liikkeenjohdon konsultteja. Mikroyritykset olivat keskimäärin alle kahden hengen yrityksiä. Kaikilla kerrostumilla oli asiakkaina kaiken kokoisia yrityksiä. Julkisen sektorin asiakkaita oli mikrokerrostuman yrityksistä ainoastaan 25 prosentilla. Yleisesti ottaen voidaan sanoa, että kerrostumat kilpailevat samoilla asiakasmarkkinoilla. Kilpailuympäristö rakentuu myös kaikenkokoisten yritysten kautta. Kaikkien kerrostumien liikevaihdosta suurin osa muodostui yhteisöstrategioista ja organisaation kehittämisestä. Muissa palveluissa oli kerrostumakohtaisia eroja.

Keskeisimmät kerrostumakohtaiset erot löytyivät toimintokohtaisista palveluista ja asiakkaiden toimialoista sekä liikevaihdon jakautumisesta kotimaahan ja ulkomaille. Kukin kerrostuma oli asiakkaiden näkökulmasta erikoistunut tiettyihin palvelutuotteisiin ja toimialoihin. Mikroyritysten osuus oli kotimaan liikevaihdosta suurin. Suurten yritysten osuus oli puolestaan suurin ulkomaisesta kysynnästä.

$\mathrm{M}$ arkkinoiden rakenteen, kilpailun ja asiakkaiden kannalta voidaan todeta, että kaikki markkinakerrostumat ovat merkityksellisiä ja toisaalta edustavat erilaisia osaamisen alueita. Näin ollen markkinoita on mielekästä kuvata kolmikerroksisena rakenteena. Se edellyttää erillistä tiedonkeruuta myös laajasta mikrotoimijoiden joukosta, joka yleensä tiedonkeruussa ja alan kuvaksissa on jätetty vähemmälle huomiolle. Kaksi- kerroksinen markkinarakenne ei anna riittävää kuvaa alasta.

\section{Professionaalistuminen}

Professionaalistumista voidaan tutkia henkilöstön taustojen avulla. Vastanneiden yritysten henkilöstömäärä oli 1331 ja näistä liikkeenjohdon konsultteja oli 668. Naisia oli 17 prosenttia konsulteista. LJK ry:n jäseniä oli 88 eli noin puolet LJK ry:n henkilöjäsenistä. Yritysten lukumäärään verrattuna järjestäytymisaste on matala. Sen osuus on vain noin prosentti alan yrityksistä. Tämä osoittaa, että ala ei ole pitkällä professionaalistumisprosessissa.

$\mathrm{H}$ enkilöstön koulutus- ja kokemustausta vaihtelee markkinakerrostumittain. Suurten yritysten henkilöstöllä oli yleensä yliopistotutkinto ja mikroyrityksissäkin 65 prosentilla. Liikkeenjohdon konsultointikokemuksen osalta ei ilmennyt kovin suuria eroja. Sen sijaan muuta työkokemusta oli mikroyritysten henkilöstöllä eniten. Vaikuttaa siltä, että suurten yritysten henkilöstön koulutustaso on korkeampi, ja vastaavasti työkokemus lyhyempi. Mikroyrityksissä taas korostuu enemmän työkokemus. Professionaalistumisen kannalta voidaan todeta, että korkeakoulututkinto ei ole edellytys, mutta on pääosalla alalla toimijoista. Siinä suhteessa ala näyttää edustavan professiopohjaista tiedeperusteisen tiedon soveltajaa.

Liikkeenjohdon konsulttien koulutustaso on hyvin kirjava: 30 prosenttiaa heistä on suorittanut teknisen alan tutkinnon, 35 prosenttia kaupallisen, 11 prosenttia käyttäytymistieteellisen ja 10 prosentilla on jokin muu koulutustausta. 14 prosentilla oli monialainen koulutus. Markkinakerrostumittain koulutustaustat eroavat toisistaan. Mikroyrityksissä painottuu tekninen ja monialainen koulutus, käyttäytymistieteiden saadessa vähemmistöaseman. Useampialainen koulutus painottuu tekniseen ja kaupalliseen. Pienissä yrityksissä kaupallinen koulutus saa eniten painoarvoa useampialaisen koulutuksen ollessa hännänhuippuna. Isoissa yrityksissä käyttäytymistieteet saavat keskiarvoon nähden merkittävän aseman. Koulutusalan pohja viestii siitä, ettei alalla ole eriytynyttä tiedeperustaa. Kasvatustieteilijän näkökulmasta 
TAULUKKO 2. Liikkeenjohdon konsultoinnin toimialan profiili markkinakerrostumittain

\begin{tabular}{|c|c|c|c|}
\hline PIIRRE & \multicolumn{2}{|c|}{ MIKROYRITYS PIENI YRITYS } & SUURI YRITYS \\
\hline \multicolumn{4}{|l|}{$\begin{array}{l}\text { LIIKEVAIHTO/yritys } \\
1000 \mathrm{mk}\end{array}$} \\
\hline Koko liikevaihto/yritys & 614 tmk $(100 \%)$ & 3600 tmk $(100 \%)$ & 42448 TMK (100\%) \\
\hline $\begin{array}{l}\text { Liikkeenjohdon konsul- } \\
\text { toinnin liikevaihto }\end{array}$ & 506 tmk $(82 \%)$ & 2615 tmk $(73 \%)$ & 15204 TMK (36\%) \\
\hline \multicolumn{4}{|l|}{ HENKILÖSTÖ/YRITYS } \\
\hline Kaikki työntekijä/yritys & 1,7 henkeä & 8,5 henkeä & 86,4 henkeä \\
\hline Liikkeenjohdon konsultti/yritys & 1,4 konsulttia & 5,3 konsulttia & 20 konsulttia \\
\hline Liikevaihto/ työntekijä & $365 \mathrm{tmk}$ & $422 \mathrm{tmk}$ & $491 \mathrm{tmk}$ \\
\hline konsultti $1000 \mathrm{mk}$ & $372 \mathrm{tmk}$ & $492 \mathrm{tmk}$ & $760 \mathrm{tmk}$ \\
\hline $\begin{array}{l}\text { Kerrostumien liikevaihdon } \\
\text { jakauma }\end{array}$ & $37 \%$ & $30 \%$ & $33 \%$ \\
\hline \multirow[t]{2}{*}{$\begin{array}{l}\text { KOKOHENKILÖSTÖ ja LIIK- } \\
\text { KEENJOHDONKONSULTIT }\end{array}$} & $402(100 \%)$ & $324(100 \%)$ & $605(100 \%)$ \\
\hline & \multicolumn{3}{|c|}{ ASIAKKAAT JA PALVELUKSET } \\
\hline Asiakkaiden koko & $\begin{array}{l}\text { KAIKENKOKOISET } \\
\text { YRITYKSET }\end{array}$ & $\begin{array}{l}\text { KAIKENKOKOISET } \\
\text { YRITYKSET }\end{array}$ & $\begin{array}{l}\text { KAIKENKOKOISET } \\
\text { YRITYKSET }\end{array}$ \\
\hline Asiakkaita julkisella sektorilla & $25 \%$ & $46 \%$ & $86 \%$ \\
\hline Osuus kotimaan markkinoista & $41 \%$ & $32 \%$ & $28 \%$ \\
\hline KOLMEKESKEISTÄPALVELUA & $\begin{array}{l}\text { 1. Yhteisöstrategiat } \\
\text { ja organisaation } \\
\text { kehittäminen } \\
\text { 2. Tuotannon ja pal- } \\
\text { velujen johtaminen } \\
\text { 3. Markkinointi ja } \\
\text { yhteisöviestintä }\end{array}$ & $\begin{array}{l}\text { 1. Yhteisöstrategiat } \\
\text { ja organisaation } \\
\text { kehittäminen } \\
\text { 2. Tuotannon ja pal- } \\
\text { veluiden johtaminen } \\
\text { 3. Talous- ja hallinto- } \\
\text { järjestelmä, henkilöstö- } \\
\text { hallinto ja henkilöstö- } \\
\text { resurssit }\end{array}$ & $\begin{array}{l}\text { 1. Yhteisöstrategiat } \\
\text { ja organisaation } \\
\text { kehittäminen } \\
\text { 2. Henkilöhallinto ja } \\
\text { henkilöstöresurssien } \\
\text { käyttö } \\
\text { 3. Talous- ja hallinto- } \\
\text { järjestelmä }\end{array}$ \\
\hline $\begin{array}{l}\text { SUURINPALVELUTUOTTEEN } \\
\text { MARKKINAOSUUS }\end{array}$ & $\begin{array}{l}\text { Projektin johtaminen } \\
\text { Markkinointi ja } \\
\text { yhteisöviestintä } \\
\text { Tuotanto ja palvelut }\end{array}$ & $\begin{array}{l}\text { Yhteisöstrategiat ja or- } \\
\text { ganisaation kehittäm. } \\
\text { Tietotekniikka ja tieto- } \\
\text { hallinnan järjestelmä }\end{array}$ & $\begin{array}{l}\text { Taloudelliset ja ym- } \\
\text { päristötutkimukset } \\
\text { Henkilöstöhallinto ja } \\
\text { henkilöstöresurssien } \\
\text { käyttö }\end{array}$ \\
\hline TOIMIALAERIKOISTUMINEN & $\begin{array}{l}\text { - majoitus ja ravitse- } \\
\text { mus } \\
\text { - kiinteistö, liike- } \\
\text { elämän palvelut } \\
\text { koulutus } \\
\text { - muut palvelut }\end{array}$ & $\begin{array}{l}\text { - kuljetus, varastot ja } \\
\text { - terveydenhuolto ja } \\
\text { sosiaalipalvelut } \\
\text { - muut palvelut }\end{array}$ & $\begin{array}{l}\text { - sähkö, kaasu ja } \\
\text { vesihuolto }\end{array}$ \\
\hline & KOULUTUS & & \\
\hline Korkeakoulututkinto & $65 \%$ & $73 \%$ & $91 \%$ \\
\hline Koulutusala & $\begin{array}{l}\text { Pitkä kokemus } \\
\text { Teknillinen, kaupalli- } \\
\text { nen ja monialainen } \\
\text { koulutus }\end{array}$ & Kaupallinen koulutus & $\begin{array}{l}\text { Käyttäytymistieteet } \\
\text { Korkeakoulukoulutus }\end{array}$ \\
\hline
\end{tabular}


käyttäytymistieteiden mukaantulo liikkeenjohdon konsultointiin merkitsee uusia markkinoita.

\section{Alalle tulo ja poistuminen}

$A_{\text {jo }}$ lalle tulo ja sieltä poistuminen on liikkeen johdon konsultoinnissa perinteisesti ollut vilkasta. Vaihtumisvirta kuvaa kypsymätöntä professionaalistumisprosessia. Tilastokeskuksen yritysrekisterin kolmea aineistoa vertaamalla voitiin luoda yleiskuva alalle tulosta ja poistumisesta.

Kolmen toimintavuoden jälkeen sekä aloittaneita että toiminnassa olevia yrityksiä oli jäljellä noin 50 prosenttiaa. Kun ottaa huomioon ensimmäisen vuoden poistuman, niin alalle rekisteröityneistä oli kolmen toimintavuoden jälkeen poistunut 70 prosenttia. Alalle ei siis ole muodostunut markkinasuojaa. Kehitys noudattelee kansainvälistä suuntausta. Vaikuttaa kuitenkin siltä, että poistuma alalta ei olisi niin suurta, kuin jotkut kansainväliset tutkimukset antavat olettaa.

\section{JOITAKIN LOPPUPÄÄTELMIÄ}

Liikkeenjohdon konsultointi on 100 vuoden historiansa aikana löytänyt itselleen paikan yhteiskunnassa. Tulevaisuudessa mitä ilmeisemmin ympäristön muutokset ja yhteiskunnallinen tilanne luovat alalle entistä enemmän markkinoita. Professionaalistumisprosessin voidaan odottaa etenevän, jos alan merkitys yhteiskunnassa kasvaa. Nykyisessä murroksessa on useita muutostekijöitä, jotka luovat sille tarvetta: EU:n kehittyminen, maailmanlaajuinen alueellistuminen, rakenteellinen työttömyys, julkisen sektorin rakenteiden purkautuminen, teknologian kehittyminen ja PK-sektorin merkityksen kasvu.

$\mathrm{E}$ nsimmäisiä hiljaisia signaaleja professionaaistumisprosessin etenemisestä on havaittavissa tiedeperusteisen tiedon ja siihen liittyvän koulutuksen osalta. Saksassa ja Hollannissa on kehitetty pitempikestoisia korkeakoulutasoisia liikkeenjohdon konsultoinnin koulutusohjelmia. Viimeisin ja ehkä pisimmälle edennyt hanke on professori Peter Jarvisin kehittämä master-tutkinto Surreyn yliopistossa Britanniassa.
Suomessa liikkeenjohdon konsultoinnin koulutuskokonaisuudet ovat vielä olleet vaatimattomasti muutaman opintoviikon laajuisia. Sama tilanne on esimerkiksi Sveitsissä. PK-sektorin merkityksen kasvu alalla näyttäytyy Suomessa PKT säätiön toiminnassa. Se on lähtenyt käynnistämään erilaisia kehittämishankkeita, koordinoimaan alaan liittyviä toimintoja, kouluttamaan liikkeenjohdon konsultteja ja kehittämään alan tiedonkeruuta. Kansainvälinen sertifiointi on myös käynnistynyt Helsingin kauppakorkeakoulussa. Se, johtavatko nämä professionaalistumisprosessin etenemiseen, nähdään tulevaisuudessa. Professiotoimialan kuvausmalli osoitti toimivuutensa liikkeenjohdon konsultoinnissa. Liiketaloustiede ja sosiologia pystyivät vuoropuheluun, jota olisi kiintoisaa kokeilla myös vakiintuneilla toimialoilla.

\section{LÄHTEET}

ABELL, D. F. (1980) Defining the business. The starting point of strategic planning. Englewood Cliffs, New Jersey: Prentice Hall Inc.

BARTELS, R. (1962) The Development of Marketing Thought. Homewood (Ill.): Richard D. Irwin.

BENNDORF, H. - Henriksson H. (1989) Ed. Framtida Perspektiv på marknadsföring. Stockholm: Marknadstekniskt Centrum.

BRYSON, J. - Keeble, D. - Wood, P. (1990) The Performance of Small Services. Managment Consultancy, November 1990 , p. 29-31.

BUSH, R.F. - Hunt, S. D. (1982) Ed. Marketing Theory: Philosophy Of Science Perspectives, 2. edition. New York: McGraw-Hill Book Co.

CYERT, R. M. - March J. G. (1963) A Behavioral Theory of The Firm. USA.

CZARNIAWSKA-Joerges B. (1988) To coin a phrase: The Study of power and democracy in Sweden. Stockholm: The Economic Research Institute Stockholm School of Economics.

DAY, G. S. - Wensley, R. (1983) Marketing Theory with a Strategic Orientation. Journal of Marketing Vol. 47 (Fall 1983), p. 79-89.

FEACO (1988) Conference presentation, Düsseldorf.

FEACO (1995) Press Release, 'Commission review procurement practices', 10 August, 1995

FREIDSON, E. (1986) Professional Powers: The Study of Institutionalization of Formal Knowledge. Chicago: University of Chicago Press.

GILBERT, X. - Strebel, P. (1991) Developing Competitive Advantage, p. 82-93. In the publication The Strategy, process, context, cases edited by Minzberg, H. - Quinn, J. B. Prentice Hall International. USA

Von GLINOW, M. A. (1988) The New Professionals: Man-aging Today's High-Tech Employees. Cambridge, Mass: Ballinger. 
COLLINS, R. (1990) "Changing conceptions in the sociology of the professions" in The Formation of Professions; Knowledge, State and Strategy edited by Torstendahl Rolf-Michael Burrage. p. 11-23 Swedish Collegium for Advance Study. SAGE Publications Ltd. Worcester.

GREINER, L. E. - Metzger R. O. (1983) Consulting to Man-agement: Insights to Building and Managing a Successful Practice. Englewood Cliffs, New Jersey: Prentice Hall Inc..

HENDERSON, B. D. (1990) Historical Perspective, Management Consulting 1990 The State of The Profession. A-Symposium-in-print on the occasion of our 20th anniversary. Kennedy Publications. Consultants News, Fitzwilliam, 1990 p. 11-13.

HUNT, S. (1976) Marketing Theory: Conceptual Foundations Of Research In Marketing, USA.

JOHNSON, T. J. (1986) Professions and Power. Studies in Sociology. 6th reprented. MacMillan Education Ltd. Hong Kong

JULKUNEN, R. (1987) Työprosessi ja pitkät aallot. Työn uusien organisaatiomuotojen synty ja yleistyminen. Tampere: Vastapaino. Sosiaalipoliittisen yhdistyksen tutkimuksia 47.

KONTTINEN, E. (1991) Perinteisesti moderniin. Professioiden yhteiskunnallinen synty Suomessa. Tampere. Vastapaino.

KOUTSOYIANIS, A. (1985) Modern Microeconomics, 2. edition. Basingstoke: Macmillan.

KYRÖ, Paula (1992) Liikkeenjohdon konsultoinnin identiteetti: liiketoimintaketjun, ammatin ja kvalifikaatiovaatimusten jäsentämänä. Helsinki. Helsingin Kauppakorkeakoulun julkaisuja B-128.

KYRÖ, Paula (1995) The Management Consulting Industry Described by Using the concept of 'profession'. Department of Education. University of Helsinki. Research Bulletin 87.

KYRÖ, Paula (1996a) Liikkeenjohdon konsultoinnin rakenteet muuttuvat. Helsingin Kauppakorkeakoulun julkaisuja D-231. Helsinki.

KYRÖ, Paula (1996b) Suomalainen liikkeenjohdon konsultointi. Toimialaraportti vuodelta 1994. PKT-säätiön julkaisu 2/1996.

KYRÖ, Paula (1997) Yrittäjyyden muodot ja tehtävät ajan murroksessa. Jyväskylä: University of Jyväskylä. Jyväskylä Studies in Computer Science, Economics and Statistics.

LAHTI, A. (1985) Yrityksen strategia ja menestyksellisyys. Helsingin Kauppakorkeakoulun julkaisuja. D69, Helsinki: Helsingin Kauppakorkeakoulu.

LAHTI, A. (1991) Entrepreneurial Strategy Making, p. 146-162, in : Arenas of Strategic Thinking. Ed. by Näsi J. Foundation for Economic Education. Helsinki

LARSON, M., S. (1979) The Rise of Professionalism. A Sociological Analysis. Berkeley, California: University of California Press.

LARSON, M., S. (1990) "In the matter of experts and professionals, or how impossible it is to leave nothing unsaid" published in The Formation of Professions; Knowledge, State and Strategy edited by Torstendahl Rolf-Michael Burrage. Swedish Collegium for Advance Study. P. 24-50. London: SAGE Publications Ltd..

LEVACIC, R. (1991) Marketse and Government: An overview. p. 35-37 and Introduction to Market p. 21-
23 In the publication Markets, Hierarchies \& Networks. The coordination of social life edited by Thompson, G. - Frances, J. - Levacic, R. - Mitchell, J. London: SAGE Publication Ltd..

MELLET, E. B. (1988) From Stopwatch to Strategy: A History of the first twenty-five Years of Canadian Association of Management Consulting. Toronto: CAMC.

MINZBERG, H. - Quinn, J., B. (1991) The Strategy Process: concepts, contexts, cases, Second edition. Englewood Cliffs, New Jersey: Prentice Hall International Inc.

PARSON, T (1954) Esseys in Sociological Theory. Revised edition. Glencoe, Ill.:The Free Press.

PARSONS, T. (1965) Unity and Diversity in the Modern Intellectual Disciplines: The Role of the Social Science. Daedalus. No. 94. p. 39-65.

PORTER, M. E. (1980) Competitive Strategy. Techniques for Analyzing Industries. New York : Free Press.

RAIVOLA, R. (1989) Opettajan ammatin historia: Opettajuus ja professionalismi. Tutkimusraportti A44. Tampere: Tampereen Yliopisto, Kasvatutieteen laitos.

RYTKÖNEN, Pekka, (1989) Liikkeenjohdon, kirjanpito- ja lakiasiain palvelu 1980-luvulla. Tilastokeskus. Tutkimuksia no 161. Helsinki.

SCHERER, F.M. (1980) Industrial market structure and economic performance. Second edition. Boston: Houghton Mifflin Company.

TEIPEL, H. N. (1990) Still a place for solos? Management Consulting 1990, The State of The Profession. A-Symposium-in-print on the occasion of our 20th anniversary. Fitzwilliam, New Hampshire : Kennedy Publications. Consultants News, 1990 p. 35-39.

THOMPSON, G. - Frances, J. - Levacic, R. - Mitchell, J. (1991) Ed. Markets, Hierarchies \& Networks. The coordination of social life. SAGE Publication Ltd. Worcester

Tilastokeskus (1991) Liike-elämän palvelut. Palvelut 1990:1. Suomen Virallinen Tilasto. Helsinki.

WEBER, M. (1969) The Theory of Social and Economic Organization. First paperback 1947. Sixth printing. Edited with an Introduction by T. Parsons New York: A Free Press Paperback Collier-MacMillan Ltd.

ZEITHAM, V. A. - Parasuraman A. - Berry L. L. (1989) Problems and Strategies in Service Marketing. p. 38-57 in the publication edited by Bateson J.E.G. Chicago: The Dryden press.

Artikkeli saapui 4.2.1999. Se hyväksyttiin julkaistavaksi 15.2.1999. 